\title{
Relationship between the price of fish and its quality attributes: a study within a community at the University of São Paulo, Brazil
}

Erika da Silva MACIEL ${ }^{1 *}$, Luciana Kimie SAVAY-DA-SILVA ${ }^{1}$, Julia Santos VASCONCELOS ${ }^{1}$, Jaqueline Girnos SONATI ${ }^{2}$, Juliana Antunes GALVÃO ${ }^{1}$, Leandro Kanamaru Franco de LIMA³ ${ }^{3}$ Marília OETTERER ${ }^{1}$

\begin{abstract}
The aim of this study was to evaluate the associations between the products' market price and attributes related to fish purchase and consumption within a university community in Brazil. A structured questionnaire consisting of a five-point Likert scale was used. It was previously tested and made available to the university community via the Internet. The sample comprised 1966 voluntaries including university students and faculty and staff members. A descriptive analysis of data was performed using Spearman's correlation analysis. The results showed that the majority of the respondents (56\%) consume fish at home; some consume fish at restaurants (39\%), and $5 \%$ at family or friends' houses, reinforcing the idea that variables such as culture and reference groups are fundamental determinants of purchase and consumption behavior. It was identified a significant $(\mathrm{p}<0.001)$ and very strong correlation between the attributes price and nutritional value $(r=0.92)$; price and availability at the usual places of purchase $(r=0.92)$; price and packaging $(r=0.92)$; price and brand name $(r=0.91)$; and price and of the Federal Inspection stamp $(r=0.91)$ and a low positive correlation $(\mathrm{p}<0.001)$ between the price variable and the initiative for fish traceability $(r=0.16)$. This study demonstrated that the price of fish is associated with the quality of the product and the attributes related to it such as packaging, nutritional value, and availability of the product in the market.
\end{abstract}

Keywords: consumer; preference; fish; quality.

\section{Introduction}

Currently, there is increasing demand for attributes of safety, social responsibility, and sustainability in the food industry.

Products with quality attributes must ensure safety for consumers through formal systems, such as certification, origin identification, and traceability of production processes (THOMPSON; SYLVIA; MORISSEY, 2005). However, consumers are more demanding in terms of their choices, and issues related to food quality are at the forefront regarding consumers' concerns, industry strategies, and in some cases, government policies. In Canada, for example, initiatives of the public policy and private sectors have emerged aiming at reducing information asymmetry to consumers regarding safety and quality attributes of food focusing, in part, on traceability (HOBBS, 2003).

Such initiatives should be encouraged considering that fish consumption is associated to health issues, which are the main attributes of interest for consumers (TRONDSEN et al., 2003; BIRGISDOTTIR et al., 2008).

One of the key factors associated to fish consumption is the people's recent interest in health, longevity, and food safety (SOUKI, 2003). Such behavior has increased fish consumption patterns and the demand for products with special characteristics that influence consumers (TRONDSEN et al., 2003).
In recent years, there has been an increased demand for fish, in part, due to the perception of its benefits to human health (MACIEL; OETTERER, 2010) and to the greater availability of fish-based products (MYRLAND et al., 2000).

Perception is a key concept to better understand various aspects of consumers' behavior. Quality is an assessment that reflects the customers' perception of five specific dimensions, namely reliability, responsiveness, safety, empathy, and tangibility. Satisfaction, on the other hand, is influenced by perceptions of the quality of services and products involved, as well as price and possible occurrence of situational and personal factors (ZEITHAML; BITNER, 2003).

However, despite the increasing demand associated with health benefits, fish consumption is still hampered by high prices, lack of product standardization, and issues regarding quality control in the production chain.

In the food sector in Brazil, consumers claim that there is too little variety of the product available, low product yield, and difficulties in finding fresh and quality products. However, despite these difficulties, the interest in fish consumption is on the rise in Brazil (UILDE; FARAH; FLÁVIA, 2002).

Surveys of consumers' demands help to identify factors that influence their purchase decision, and these results allow 
proposing changes to meet consumers' expectations (KOTLER, 2000).

Thus, understanding the factors related to fish consumption and demand is important not only for the market, but also for the implementation of public policies that encourage fish consumption and consequent improvement of lifestyle, given the relationship between fish consumption, health, and lifestyle (TRONDSEN et al., 2003).

Therefore, the objective of this research was to determine the attributes related to the purchase decision and fish consumption that are associated with the perception of the product price.

\section{Materials and methods}

\subsection{Samples}

Research participants are non-probabilistic samples, convenience sampling, and consisted of a community of the University of São Paulo (USP) including the voluntary participation of students and staff of the Campi of São Paulo, Piracicaba, Pirassununga, São Carlos, Ribeirão Preto, Lorena, and Bauru.

In 2010, the University of São Paulo had a student and staff population of 108,636 . A representative sampling was calculated in order to determine the population that should be analyzed with a sampling error of $2 \%$ and a significance level of $95 \%$, resulting in the ideal number of 8,305 questionnaires to be answered, corresponding to $7.64 \%$ of the entire university community. Considering the stratification based on geographical location, it resulted in 2216 people in São Paulo, 1.431 in Ribeirão Preto, 1.226 in São Carlos, 1.116 in Piracicaba; 827 in Bauru; 748 in Pirassununga, and 741 in Lorena.

However, it was impossible to calculate the random sampling because there was no access to a staff and student directory including entire university community. Therefore, it was not be possible to send specific messages and control the email accounts of all USP users. Thus, an invitation to participate in the research project was sent via e-mail to the units, students, and staff members who had electronic contact in their home Page aiming at reaching the largest possible number of invitations sent to university users of e-mail.

\subsection{Research instrument (Questionnaire)}

A previously tested questionnaire was used to assess fish consumption perception and the importance of product quality attributes. It consisted of a five-point Likert scale and the data were collected from the Internet (MACIEL, 2011).

The questionnaire was made available on a specific homepage of the Study Group and Extension of Technological Innovation and Quality of Fish (GETEP), College of Agriculture "Luiz de Queiroz" (ESALQ - USP) in the municipality of Piracicaba, São Paulo state - Brazil. E-mails were sent inviting USP staff members and students to voluntarily participate to collect research data. The research was disseminated through social media, websites of some research institutes and offices, electronic newsletters, speeches, brochures, and posters affixed on bulletin boards throughout the campuses.
By accessing the website, the participant had access to information on the Statement of Informed and Free Consent (IFC) of the study and researchers 'contact information, and, therefore, participants could choose to fill out the forms by providing their institutional e-mail account and their USP ID number. This study was approved by the Ethics Committee for Research with humans ESALQ - USP, (protocol 046). The research participants' personal information was kept secret.

\subsection{Statistical analysis}

A descriptive analysis of the samples, frequency analysis of responses, and an analysis of the importance of attributes were conducted as well as tests of data normality and homoscedasticity. The Spearman correlation analysis was conducted to verify a probable relationship between price and each one of the attributes: "nutritional value", "availability in the usual places of purchase", "packaging", "brand name", "Stamp of the official inspection agency" and "fish traceability". The statistical software SPSS 15.0 was used for the analyses.

\section{Results}

Participation in the research was voluntary, and it consisted of 1,966 subjects who belong to the USP university community. The sample profile (Table 1 ) indicates that the most volunteers in the research were women $(61.6 \%)$, most of the volunteers were married (65.9\%) and undergraduate students (52.6\%).

Table 1. Sample profile of USP university community/2010.

\begin{tabular}{|c|c|c|}
\hline Variable & Number & $\%$ \\
\hline \multicolumn{3}{|l|}{ Marital status } \\
\hline Single & 1,295 & 65.9 \\
\hline Married & 455 & 23.1 \\
\hline Living as married & 139 & 7.1 \\
\hline Divorced & 69 & 3.5 \\
\hline Widow/widower & 8 & 0.4 \\
\hline \multicolumn{3}{|l|}{ Sex } \\
\hline Male & 754 & 38.4 \\
\hline Female & 1,212 & 61.6 \\
\hline \multicolumn{3}{|l|}{ Category } \\
\hline Undergraduates & 1,035 & 52.6 \\
\hline Graduates & 347 & 17.7 \\
\hline Employees & 303 & 15.4 \\
\hline Faculty member & 248 & 12.6 \\
\hline Others & 33 & 1.7 \\
\hline \multicolumn{3}{|l|}{ Campi } \\
\hline Bauru & 23 & 1.1 \\
\hline Lorena & 62 & 3.1 \\
\hline Piracicaba & 482 & 24.5 \\
\hline Pirassununga & 84 & 4.2 \\
\hline Ribeirão Preto & 240 & 12.2 \\
\hline São Carlos & 59 & 3.0 \\
\hline São Paulo & 1000 & 50.8 \\
\hline Others * & 16 & 0.8 \\
\hline Average age (years) & 30,4 & $( \pm 12.41)$ \\
\hline
\end{tabular}

${ }^{\star}$ Research Centers located outside Campi. $\mathrm{n}=1,966$ voluntaries. 
The results of the frequency of fish consumption indicated that $27.1 \%$ of the participants consumed fish once a week, followed by those that consumed fish two to three times a month $(25.9 \%)$; once a month $(17.4 \%)$, and rarely consumed fish (14.8\%). Among the participants, 9.5\% consumed fish twice a week as recommended by FAO (FOOD..., 2009). It was noted, however, that among those who consumed fish as recommended by FAO (187 participants), $60.9 \%$ had nutritional status within the normal range, and $74.3 \%$ were physically active; most of them were women $(59.3 \%)$, undergraduate students $(42.7 \%)$ of the São Paulo Campus (60.9\%).

Most participants (54.6\%) do not usually buy fish. The others $(45.4 \%)$ purchase the product from supermarkets (61.3\%), fish markets (11.6\%), specialized stores (9.3\%), street market (9.1\%), municipal markets (6.7\%), and directly from the producers/fisherman (1.9\%).

Regarding the places of consumption, the results indicate that most participants consumed fish in their own homes (56.0\%). The others ate it at restaurants (39\%), and a small portion of the sample consumed in the house of family and friends (5\%).

The research instrument used in this study is an evaluation scale of attributes (Table 2), which demonstrates the importance of some fish attributes: "taste", "color", "smell", "texture", "Stamp of the official inspection agency on the package", "nutritional value", and "place of origin" are highlighted as the most significant. (2011).

The data collection instrument was developed by Maciel
Spearman correlation analysis considered the attributes related to the decision-making regarding the purchase and the price of product. The results indicated that there is a strong association between most attributes, showing statistically significant association in all correlations analyzed.

\section{Discussion}

The results of the price attribute indicated that $46.6 \%$ of participants considered the price paid for fish as very important. Associations of the "price" paid for the product with the attributes of "nutritional value", "availability", and "packaging" had values of $r=0.92$ (Table 3 ), indicative of a very strong positive correlation. The same result was observed between "price" and "brand name" and "price" and "SIF stamp" on the package $(r=0.91)$. Only the association between "price" and "initiative to fish traceability" was low $(\mathrm{r}=0.16)$, according to recommendations to Levin and Fox (2004).

These results suggest that, in the present study, as people give importance to the price paid for the product increases, the importance given to other quality attributes also rises. For example, the greater the importance given to price, the greater interest in nutritional value, in the place where they usually purchase the product, the packaging, the brand name, and the stamp of the official inspection agency on the package, which are attributes related to product quality.

The greater interest in fish in recent years has resulted in higher prices, which is associated with the perception that fish consumption is associated with good health and boosted trading

Table 2. Frequency of responses of the items evaluated in the Likert scale. USP university community/2010.

\begin{tabular}{|c|c|c|c|c|c|}
\hline \multirow{2}{*}{$\begin{array}{l}\text { How important are the following } \\
\text { attributes? }\end{array}$} & \multicolumn{5}{|c|}{ Scale and responses (\%) } \\
\hline & Nothing & Very little & Fair & Very much & Extremely \\
\hline Taste & 0.5 & 1.4 & 9.8 & 55.9 & 32.4 \\
\hline Size & 6.6 & 27.8 & 47.8 & 16.2 & 1.5 \\
\hline Smell & 0.8 & 4.1 & 15.2 & 36.3 & 43.6 \\
\hline Color & 2.1 & 6.4 & 18.2 & 41.8 & 31.4 \\
\hline Texture & 0.8 & 1.7 & 10.9 & 49.3 & 37.2 \\
\hline Price & 0.2 & 3.9 & 35.1 & 46.6 & 14.2 \\
\hline Nutritional Value & 1.2 & 8.6 & 22.6 & 46.2 & 21.4 \\
\hline Brand & 9.0 & 2.5 & 38.6 & 23.2 & 3.7 \\
\hline Availability at the usual places of purchase & 0.1 & 3.5 & 20.6 & 57.6 & 18.2 \\
\hline $\begin{array}{l}\text { Stamp from the official inspection agency } \\
\text { on the package }\end{array}$ & 5.1 & 9.0 & 16.3 & 30.1 & 39.5 \\
\hline *Packaging & 0.9 & 8.1 & 21.7 & 47.3 & 21.9 \\
\hline${ }^{*}$ Origin & 3.1 & 8.9 & 29.3 & 38.8 & 20.0 \\
\hline \multirow{2}{*}{$\begin{array}{l}\text { How do you evaluate your knowledge of } \\
\text { the nutritional value of fish? }\end{array}$} & 5.0 & 26.3 & 42.1 & 20.7 & 5.8 \\
\hline & Very unsatisfied & Unsatisfied & $\begin{array}{l}\text { Neither satisfied } \\
\text { nor unsatisfied }\end{array}$ & Satisfied & Very satisfied \\
\hline \multirow{2}{*}{$\begin{array}{l}\text { Are you satisfied with the fish quality } \\
\text { available in the market? }\end{array}$} & 2.1 & 18.3 & 46.2 & 31.9 & 0.8 \\
\hline & Very bad & Bad & $\begin{array}{l}\text { Neither bad nor } \\
\text { good }\end{array}$ & Good & Very good \\
\hline How do you rate the initiative to trace fish? & 0.2 & 0.5 & 26.0 & 31.6 & 41.6 \\
\hline
\end{tabular}

*a medium option was used (do not consider or consider). 
Table 3. Spearman's rank correlation between price and purchase attributes. USP university community/2010.

\begin{tabular}{lcc}
\hline \multicolumn{1}{c}{ Price paid for the fish } & $\mathrm{r}$ & $\mathrm{p}$ \\
\hline Nutritional value & 0.92 & $<0.001$ \\
Availability in the usual places of purchase & 0.92 & $<0.001$ \\
Package & 0.92 & $<0.001$ \\
Brand name & 0.91 & $<0.001$ \\
Stamp of the official inspection agency on the & 0.91 & $<0.001$ \\
package (SIF)* & & \\
Initiative to fish traceability & 0.16 & $<0.001$ \\
\hline *SIF = in Portuguese $=$ Selo de Inspeção Federal-Stamp of the official inspection agency \\
on the package. $\mathrm{n}=1,966$ voluntaries.
\end{tabular}

of fish and fishery products, increasing their availability in usual places of purchase (TRONDSEN et al. 2003).

Research has shed light on consumers' motives and barriers to fish consumption, and price is the most important factor (VERBEKE; VACKIER, 2005).

Kotler (2000) reinforces this premise by explaining that among many other perceptions, it is essential that consumers have the feeling that they paid a fair price for the quality offered. At this point, a trust in the brand name is more important than the product itself.

It is important to consider that in studies on perception of fish consumption in regions where fish has a high price, this attribute becomes a limiting factor for consumption (MYRLAND et al., 2000; TRONDSEN et al., 2004).

Kubitza (2002) emphasizes that other parameters are also considered by the consumer in the perception of fish quality, namely the general appearance of the product (color, perception of cleanliness, and hygiene), packaging, information supplied by the manufacturer (nutritional value, product origin, ingredients, and other details that characterize the product and elucidate the main questions of the potential buyer), and records of official inspection services among other things.

In the present study, the majority (46.2\%) of the respondents is not concerned with the product availability in the Brazilian market, and a significant part of the participants considers fish traceability a good $(31.6 \%)$ or very good $(41.6 \%)$ initiative.

A study conducted in Canada showed that between 10 and $33 \%$ of consumers are willing to pay more for a traced animalorigin product (HOBBS, 2003).

Wang et al. (2009), in a study carried out in China, found that $85.7 \%$ of consumers recognized that the price of fish and fishery products tend to increase with the implementation of a traceability system. However, $21 \%$ of consumers were not willing to pay more for traceability, and $60.1 \%$ was willing to pay up to $10 \%$ more for the traced fish and fishery products taking into account the increased safety of these products.

Some consumers are aware of their inability to distinguish the quality of fish in natura and prefer to rely on industrialized products that have the quality associated with an already established brand name in the market (KUBITZA, 2002).
However, eating habits encompass a variety of determinants including socio-economic factors, beliefs, knowledge, and local availability (TRONDSEN et al., 2003, 2004).

The results of place of purchase and place of consumption reinforce the idea that variables such as culture and reference groups significantly determine the purchase decision and fish consumption (UILDE; FARAH; FLÁVIA, 2002).

In a study conducted in Norway, the limiting factors for fish consumption were the availability, preparation, and preference. Fish consumption was also associated with a diet based on healthier foods (TRONDSEN et al., 2003).

Harris, Knight and Worosz (2006) reported that supermarkets may be preferred because of their choice of options, ambience, and confidence in quality inspection. Furthermore, supermarkets provide more information about origin, hygiene, and sanitation providing better guarantee for a safe product.

However, a study conducted in China, where 286 men and women were interviewed, showed that most prefer to buy fish products in bulk (65\%) and fresh (75.2\%) rather than packaged or frozen. Most consumers (67.5\%) believe that the fish products available in the market meet their basic demands, and approximately $58.6 \%$ of respondents buy fish products at supermarkets (WANG et al., 2009).

The results of the present study are similar to those obtained from studies on 246 consumers in the states of São Paulo (capital and Jundiaí), Sergipe (Aracajú), Ceará (Fortaleza), Rio de Janeiro (capital), and Mato Grosso do Sul (Campo Grande). The results showed that the factors that hinder fish purchase decision are: ability to identify fresh fish; high price in relation to chicken, beef, and pork; presence of backbone; need to clean it before consuming. As for consumption, $16.8 \%$ of respondents said they eat fish three times a month in the Northeastern coastal capitals (Aracajú and Fortaleza), and in Piracicaba (SP); $35 \%$ of respondents reported eating fish at least once a week (KUBITZA, 2002).

Wang (2003) and Zhou (2004) highlight that even in China, where fish is staple food, consumers are concerned about the lack of safety of fish products.

Fish is a perishable food; therefore, food safety is a market niche, given the demand for high quality products and food safety issues (WEI; ZENG, 2005).

The consumer's perception towards the features related to fish consumption tends to be influenced by cultural differences; however, the conception of fish as a protective food is a consensus, as verified in the literature (TRONDSEN et al., 2003; VERBEKE; VACKIER, 2005; PIENIAK; VERBEKE; SCHOLDERER, 2010).

Given that participation in our study was voluntary and most participants were women, this may indicate that women are more interested in issues related to life quality and health (MACIEL, 2006).

A study conducted in Norway with women 30-44 years showed that fish consumption increases with age. Price was 
identified as an important attribute that limits the consumption of fish (MYRLAND et al., 2000).

A study conducted in Belgium, Holland, Denmark, Poland, and Spain, to identify potential differences in fish consumption, found that consumers believe that fish consumption is healthy and that the level of education and age contribute to the frequency of consumption. However, when these variables were correlated with consumption, the results show low association, indicating that consumption is also influenced by other factors. The authors suggest that communication alone seems insufficient to achieve a higher level of compliance with the recommendations for fish consumption; however, the authors recommend that information associating fish consumption to health benefits may be a more interesting path (PIENIAK; VERBEKE; SCHOLDERER, 2010).

Thus, consumers'education should be the focus so that they can deal with all of the information concerning food safety while monitoring food companies.

In addition, public health agencies must include information on fish consumption benefits through multiple communication channels (RASPOR, 2006).

\section{Conclusion}

This study demonstrated that as the importance given to product price increases, the interest in a higher-quality product also increases and quality-related attributes are taken into account, such as packaging, nutritional value, and availability in the usual places of purchase.

The correlation between the attributes price and quality reinforces the assumption that consumers are increasingly more demanding about fish, which requires more investment in the production chain in order to ensure better quality to the final product.

The data collection system and the proposed research instrument used proved effective in evaluating fish consumption in the university environment since they show the main obstacles regarding fish consumption. The methods also indicated consumer's perception that with regards to fish products when features such as safety, quality, traceability, high nutritional value, and availability are required, the product is worth the higher price.

\section{Acknowledgements}

The authors are grateful to the CNPq (National Counsel of Technological and Scientific Development) for the scholarship granted to the first author. The authors also gratefully acknowledge FAPESP (São Paulo Research Foundation) for the financial support.

\section{References}

BIRGISDOTTIR, B. E. et al. Validity of a food frequency questionnaire to assess intake of seafood in adults in three European countries. Food Control, v. 19, p. 648-653, 2008. http://dx.doi.org/10.1016/j. foodcont.2007.07.003
FOOD AND AGRICULTURE ORGANIZATION OF THE UNITED NATIONS - FAO. The State of world fisheries and aquaculture (SOFIA) 2008. Rome, 2009. 196 p.

HARRIS, C. A.; KNIGHT, S.; WOROSZ, M. R. Shopping for food safety and the public trust: What supply chain stakeholders need to know about consumer attitudes. Food Safety Magazine, p. 52-59, June/July 2006.

HOBBS, J. E. Consumer demand for traceability. In: INTERNATIONAL AGRICULTURAL TRADE RESEARCH CONSORTIUM ANNUAL MEETING, 2002, Monterey. Proceedings... Saskatoon: Department of Agricultural Economics, University of Saskachewan, 2003. Working Paper, 3.

KOTLER, P. Administração de marketing: a edição do novo milênio. São Paulo: Prentice Hall, 2000. 765 p.

KUBITZA, F. Com a palavra os consumidores. Revista Panorama da Aquiicultura, v. 69, p. 48-53, 2002.

LEVIN, J.; FOX, J. A. Estatística aplicada a ciências humanas. 9. ed. São Paulo: Pearson, 2004. 392 p.

MACIEL, E. S.; OETTERER, M. O desafio da alimentação como fator de qualidade de vida na última década. In: VILARTA, R. (Org.). Novos padrões alimentares e as relações com os domínios da qualidade de vida e saúde. Campinas: IPES, 2010. cap. 2, p. 18-26.

MACIEL, E. S. Qualidade de vida: análise da influência do consumo de alimentos e estilo de vida. 2006. 184 f. Dissertação (Mestrado em Ciências)-Escola Superior de Agricultura "Luiz de Queiroz", Universidade de São Paulo, Piracicaba, 2006.

MACIEL, E. S. Perspectiva do consumidor perante produto proveniente da cadeia produtiva de tilápia do Nilo rastreada (Oreochromis niloticus). 2011. 304 f. Tese (Doutorado)Universidade de São Paulo, Piracicaba, 2011.

MYRLAND, $\varnothing$. et al. Determinants of seafood consumption in Norway: lifestyle, revealed preferences, and barriers to consumption. Food Quality and Preference, v. 11, p.169-188, 2000. http://dx.doi. org/10.1016/S0950-3293(99)00034-8

PIENIAK, Z.; VERBEKE, W.; SCHOLDERER, J. Health-related beliefs and consumer knowledge as determinants of fish consumption. Journal of Human Nutrition and Dietetics, v. 23, n. 5, p. 480-488, 2010. PMid:20831707. http://dx.doi.org/10.1111/ j.1365-277X.2010.01045.x

RASPOR, P. Faces of foods on the world of food systems (Editorial). Acta Alimentaria, v. 35, n. 3, p. 247-249, 2006.

SOUKI, G. Q. et al. Atributos que afetam a decisão de compra dos Consumidores de Carne Bovina. Revista de Administração da UFLA, v. 5, n. 2, p. 36-51, 2003.

THOMPSON, M.; SYLVIA, G.; MORISSEY, M. T. Seafood traceability in the United States: current trends, system design, and potential applications. Comprehensive Reviews in Food Science and Food Safety, v. 1, p. 1-7, 2005. http://dx.doi.org/10.1111/j.1541-4337.2005. tb00067.x

TRONDSEN, T. et al. Health and seafood consumption patterns among women aged 45-69 years. A Norwegian seafood consumption study. Food Quality and Preference, v. 15, p. 117-128, 2004. http://dx.doi. org/10.1016/S0950-3293(03)00038-7

TRONDSEN, T. et al. Perceived barriers to consumption of fish among Norwegian women. Appetite, v. 48, p. 301-314, 2003. http://dx.doi. org/10.1016/S0195-6663(03)00108-9

UILDE, A. G.; FARAH T. G.; FLÁVIA, M. M. Caracterização do consumo de carnes no Brasil. Revista Nacional da Carne, n. $310,2002$. 
VERBEKE, W.; VACKIER, I. Individual determinants of fish consumption: application of the theory of planned behavior. Appetite, v. 44, n. 1, p. 67-82, 2005. PMid:15604034. http://dx.doi. org/10.1016/j.appet.2004.08.006

WANG, Z. The perception of food safety and purchase behaviorcasefrom Tianjing. Journal of China Agricultural Economics, v. 4, p. 41-48, 2003.

WANG, F. et al. Consumer's perception toward quality and safety of fishery products, Beijing, China. Food Control, v. 20, p. 918-922, 2009. http://dx.doi.org/10.1016/j.foodcont.2009.01.008
WEI, X.; ZENG, Y. Consumer's attitudes and willingness-to-pay for Green food in Beijing. 2005. p. 1-10. Disponível em: <http:// sard.ruc.edu.cn/zengyinchu/files/taolunwengao/> Acesso em: 05 fev. 2011.

ZHOU, J. H. Consumer's attitude, perception and purchase behavior - Case from Jiangsu province. Journal of China Agricultural Economics, v. 11, p. 44-52, 2004.

ZEITHAML, V. A.; BITNER, M. J. Marketing de serviços: a empresa com foco no cliente. 2nd ed. Porto Alegre: Bookman, 2003. 536 p. 